The study of producer gas is to receive greater attention in view of its present importance in beavy industry and its potential application to mechanical transport. Great store is laid by the coal industry on the open coal fire, and efforts aro being mado to minimize its admitted defects-smoke and labour. It is recognized that coal-burning appliances have suffered in comparison with gas and electrical appliances owing to the neglect of scientific principles in design, and it is hoped to raise the standards of performance and eliminate inferior and ineffective appliances. Efforts are being made to advance the use of coal for cooking. A solid fuel cooker has boen designed for use on railways. Some of these have been installed on trains, including the Coronation Scot. It is believed that gravity feed firing will play a considerable influence on hotel and institution cookery in the future.

\section{Collective and Economic Security}

Politrcal and Economical Planning (P E P) has issued two broadsheets dealing with the economics of collective security and instruments of economic security. In the former, relations between economic policy and a fresh effort to realize collective security are discussed and the necessity of military support for economic collaboration is emphasized, and the importance of ascertaining how far geography and the balance of strategic forces would permit military assistance if needed before inviting smaller countries into a system of collective economic security. The maintenance of peace through collective political and economic security involves the application of principles similar to those which would be appropriate in time of war. The measures of self-defence now required of a system of collective security may be classified as those required for preserving and pro. moting the free exchange of goods and services between members of the system; steps needed to ensure that the advantages of participation in economic relations on those terms should no longer be available to nations which do not subscribe to the conceptions inherent in the free exchange system and which now only participate in that system to destroy; and measures for extending assistance to neutral countries to enable them with safety to enter the orbit of the free system. Civilization's resources, it is urged, should be used to maintain civilization, and the main economic implications of a policy of collective security are discussed in some detail, including the question of reciprocal aid, the utilization of limited resources, the difficulty of overvalued currencies, the possibility of organizing markets and Nazi political and economic exploitation. If civilization is to be preserved it cannot be in isolation. Its basis is international, and there is no alternative to collective measures.

THE second broadsheet, emphasizing the need for industrial reorganization, classifies the possible measures under four heads, according to their connexion with Government commercial policy, with the improvement of trading methods, with the finance of international trade and with export and import subsidies. The absence of any coherent British trade policy is criticized. The United Kingdom has a strong bargaining weapon for securing increased reciprocity in commercial relations with individual States in view of the importance to them of British import purchases, and it is suggested that 'most favoured nation' treatment might be withheld from countries which resort to unfair trade practices. Ifuch could still be done to improve the mechanism of economic co-operation and the importance of control schemes and cartels being operated in the public interest and particularly in the interests of economics is stressed. The questions of export credits, import subsidy, and of selecting the appropriate measure for different purposes are then discussed, the final emphasis being laid on the need for more moral courage to form the nucleus of a system of collective economic security in which the benefits of free exchange would be limited to the free exchange group.

\section{Employment in $193^{8}$}

THE report of the Ministry of Labour for the year 1938 shows that on the average for the year the numbers in employment were about 120,000 less than in 1937 although higher than in any previous year except 1937, and more than 20 per cent higher than in 1924, when the series of comparable statistics was begun (Cmd, 6016. London : H.M. Stationery Office, 1939. 2s. net). The seasonal fluctuations were less than usual, the maximum variation in the rate of unemployment among insured persons in the general scherne being only 0.5 per cent as against variations of from 2 to 5 per cent in previous years. Seasonal improvement in the first half of the year, however, was much less marked than usual in the building and contracting industries, brick manufacture and the distributive trades, and was almost entirely offset by a decline in metal and metal goods manufacture, engineering, the textile industries, especially in the cotton industry, and the normal slackening in coal mining. In the second half of the year the seasonal declino in building and public works contracting, transport, distribution and the hotel and boardinghouse service was counterbalanced by improvements in the textile industries, metal goods manufacture, and the vehicle and mining industries. The effects of the recession of 1937-38 were spread very unevenly over different areas of the country, being most marked in the north-western area, in which employment declined by $7 \cdot 5$ per cent, mainly through contraction in the cotton industry. Wales suffered severely with a fall of 5.4 per cent, mainly in the iron and steel and tin-plate industries. In the Midlands there was a fall of 3.4 per cent and in the south-eastern division no change.

Referexce is made in the report to the policy of the Ministry in regard to the admission of foreign workers. Of the 22,347 permits granted during the year, 61.7 per cent were for employment in private domestic service. The figures do not include persons 